\title{
Is the incidence of registrable age-related macular degeneration increasing?
}

Glaxo Department of

Ophthalmic

Epidemiology,

Institute of

Ophthalmology,

Moorfield's Eye

Hospital, City Road,

London EC1V 2PD

J Evans

R Wormald

Correspondence to: Jennifer Evans.

Accepted for publication 8 August 1995

Jennifer Evans, Richard Wormald

\begin{abstract}
Aims/Background-Age-related macular degeneration (ARMD) is a growing public health problem in Britain; currently its aetiology is unclear. The aim of this study was to test the hypothesis that the age specific incidence of blinding ARMD has increased in Britain in the past 50 years, using data on cause of visual loss in people registered as blind, published every 10 years since 1950.

Methods-Data were abstracted from published sources for the years 1950,1960 , 1970, and 1980. Data for the standard year, 1990, were provided in a database from the Office of Population Censuses and Surveys. The numbers of new registrations attributed to ARMD per head of population were compared with registrations for cataract, glaucoma, and optic atrophy. Indirect standardisation was used to control for changes in the age structure of the population over time.

Results-After controlling for changes in the age structure of the population, registration rates for all causes, cataract, glaucoma, and optic atrophy have decreased while registrations attributed to ARMD have increased in the order of $30-40 \%$. Conclusions-These findings are compatible with the hypothesis that the incidence of ARMD is increasing in Britain. It is difficult to exclude potential sources of bias in these data, however, particularly with respect to classification and coding of cause; more reliable population based data on ARMD in Britain are needed.

(Brf Ophthalmol 1996; 80: 9-14)
\end{abstract}

Since the pioneering work of John Graunt who analysed weekly Bills of Mortality in the 17 th century, mortality data have been used to monitor trends, both for assessing the relative burden of disease in the population and for generating hypotheses on aetiology. ${ }^{1}$ Since 1920 , registration has been the legal mechanism by which social services for the blind are coordinated in England and Wales. There are parallels between registration data and mortality data: death rate due to a particular disease is a function both of the incidence and treatability of that disease; registration for blindness is usually recommended by ophthalmologists when it is felt that no treatment is available to restore sight. Thus the number of people registered blind each year is a function of both incidence and treatability of a condition. The important difference between the two processes is that death certification is compulsory whereas registration for blindness is voluntary. There was a review of the registration process in $1983^{2}$ which led to the revision of the certificate of blindness (BD8 form) and development of a computerised database on cause of registration in individuals.

There are estimated to be nearly 1 million people visually impaired in Britain, $90 \%$ of whom are over 65 years of age. ${ }^{3}$ Age-related macular degeneration (ARMD) is one of the most frequently occurring visually impairing eye diseases in this age group. Annually, 35000 people are registered as blind or partially sighted, $50 \%$ from degeneration of the macula. ${ }^{4}$ With extended life expectancy, such age-related degenerative conditions will have an increasing public health impact. ARMD is largely untreatable and currently its aetiology is unclear, although it appears to be largely confined to Western industrialised populations. It has been observed that ARMD shares common risk factors with cardiovascular disease, being associated with, for example, cigarette smoking and raised serum cholesterol levels. ${ }^{5}$ Current research is aimed at assessing the role of genetic factors ${ }^{6}$ chronic light damage, ${ }^{7}$ and the possible protective effect of antioxidant nutrients. ${ }^{8}$

Little is known about trends in ARMD in the population over time. In this paper we examine the only available national source of data on this condition and compare trends in registration of ARMD with other blinding conditions cataract, glaucoma, and optic atrophy.

\section{Methods}

SOURCES OF DATA

Publications of registration by cause cover the period 1933-1991. ${ }^{4-19}$ Since 1960, registration statistics by cause for all ages have been published only every 10 years; before 1950 a selected sample of certificates only were analysed. For this reason, trends over time were assessed using data from the single years $1950,{ }^{10} 1960,{ }^{12} 1970,{ }^{14} 1980,{ }^{16}$ and 1990 (supplied on a database by Office of Population Censuses and Surveys (OPCS), St Catherine's House, 10 Kingsway, London WC2B 6JP). In 1950 and 1990, data were published for England and Wales combined, for 1960-80 data for England only were available. Table 1 presents the percentage of registrations for which certificates were available for analysis of cause.

DEFINITION OF ARMD

The terminology used in the routine publications to describe blinding age-related 
Table 2 Terminology used to describe age-related macular degeneration, cataract, glaucoma, and optic atrophy

\begin{tabular}{|c|c|c|c|c|}
\hline Year & $A R M D$ & Cataract $^{\star}$ & Glaucoma & Optic atrophy \\
\hline 1950 & Senile macular degeneration & Cataract, primary senile & $\begin{array}{c}\text { Glaucoma, } \\
\text { primary }\end{array}$ & Optic atrophy \\
\hline $\begin{array}{l}1960 \\
1970 \\
1980(\text { ICD-9) } \\
1990 \text { (ICD-9) }\end{array}$ & $\begin{array}{l}\text { Senile macular lesions } \\
\text { Macular lesions } \\
\text { Degeneration of macula and posterior pole } \\
\text { Degeneration of macula and posterior pole }\end{array}$ & $\begin{array}{l}\text { Cataract 'senile' } \\
\text { Cataract } \\
\text { Cataract, excluding congenital } \\
\text { Cataract, excluding congenital }\end{array}$ & $\begin{array}{l}\text { Glaucoma } \\
\text { Glaucoma } \\
\text { Glaucoma } \\
\text { Glaucoma }\end{array}$ & $\begin{array}{l}\text { Optic atrophy } \\
\text { Optic nerve atrophy } \\
\text { Optic atrophy } \\
\text { Optic atrophy }\end{array}$ \\
\hline
\end{tabular}

*Congenital cataract not included for $1950,1960,1980,1990$. For 1970, report is unclear as to whether congenital cataract is tabulated under 'cataract' or 'congenital anomalies'.

changes of the macula is set out in Table 2. Before 1970 registration statistics were analysed by Sorsby who used the terms 'senile macular degeneration' and 'senile macular lesions'. From 1980 onwards the International Classification of Diseases ${ }^{20}$ was used. 'Degeneration of the macula and posterior pole' (ICD-9 362.5) is the category to which macula holes and toxic maculopathy are also coded. In 1970 the term 'macular lesions' was taken to represent ARMD. This category largely consisted of cases in patients over 65 years of age but the report gives no information as to why the prefix indicating the changes to be age related was dropped. ${ }^{14}$

\section{CONTROLLING FOR CHANGES IN THE AGE STRUCTURE OF THE POPULATION}

Indirect standardisation was used to adjust for the potentially confounding effects of changes in the age structure of the population over the time period. This choice was dictated by the availability of data; in previous years data for limited age groups only were published and the age groups have changed, precluding direct comparison of age specific rates. The age specific registration rates for 18 five year age groups (0-5 years up until 85+) for 1990 were applied to the populations in previous years to calculate the expected number of registrations. The population figures used were mid year estimates published by the government. ${ }^{21}$ In order to reflect the population at

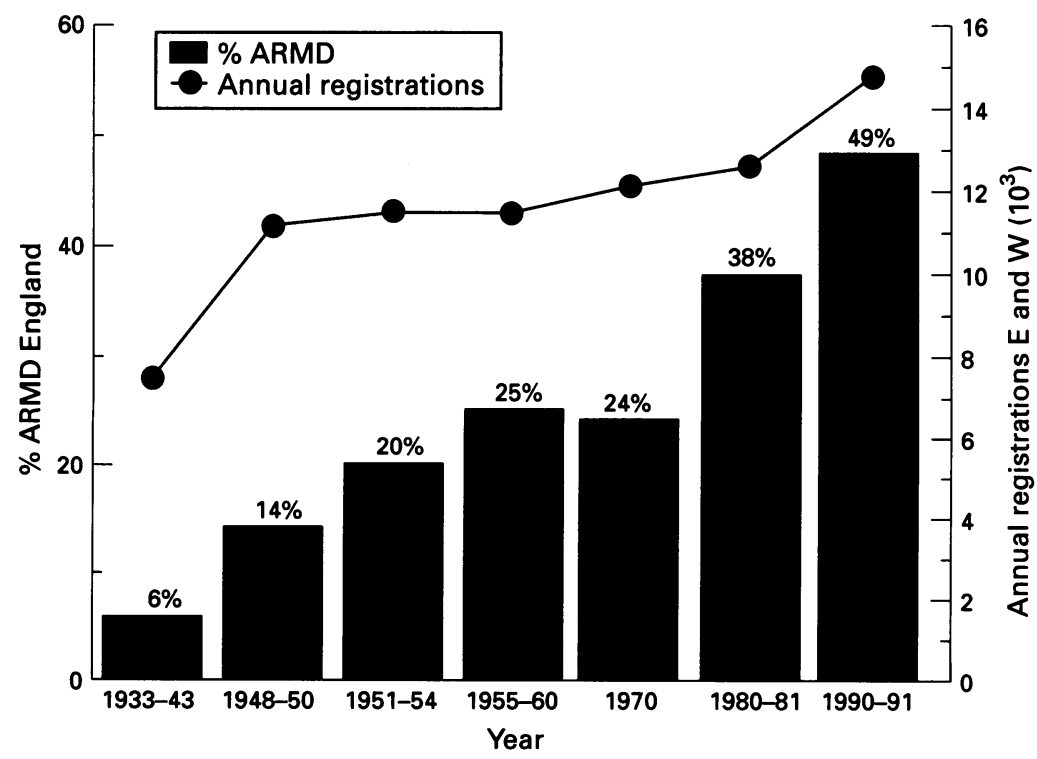

Figure 1 Annual new registrations for blindness in England and Wales 1933-90 and proportion of registrations attributed to age-related macular degeneration (ARMD) in England. risk from which the analysed registrations were drawn the population figures for England only were used for 1960, 1970, and 1980 while for 1950 and 1990 the population for England and Wales was used. The standardised registration ratio (SRR) compares the observed number of registrations in the year with the number of expected registrations. It can also be defined as a weighted average of the age specific rate ratios. ${ }^{22}$ No data were available to test whether the age specific rate ratios summarised were homogeneous. Examination of changes in the age specific rates in very limited age groups for 1980 and 1990 did not give any evidence to suggest that the trends presented are misleading.

Confidence intervals were calculated assuming the number of registrations (D) to come from a Poisson distribution with the standard error of the $\log S R R=1 / \operatorname{sqrt}(D)$ (Breslow and Day, ${ }^{22}$ p 69). The significance of trends over time was tested using the $\chi^{2}$ test for trend (Breslow and Day, ${ }^{22}$ p 96).

\section{CONTROLLING FOR DIFFERENCES IN THE} PERCENTAGE OF REGISTRATIONS FOR WHICH DATA ARE AVAILABLE

In 1990 , the standard year, 14756 registrations were made and 13950 certificates were analysed - that is, the cause of blindness in $95 \%$ of registrations was available. In previous years this percentage ranged from $72 \%$ to $93 \%$ (Table 1). In order to adjust for these fluctuations, the observed registrations for previous years for ARMD, cataract, glaucoma, and optic atrophy were multiplied by the ratio of the percentage analysed in each year by the percentage analysed in the standard year and the SRRs recalculated. This analysis, therefore, estimates the trends if the percentage of registrations analysed had been constant at $95 \%$ over the 5 years analysed.

\section{Results}

CRUDE TRENDS

Figure 1 shows the crude data abstracted from the routine publications covering the period 1933-91, using the (unequal) year groupings (x-axis) for which data were published. The absolute number of new cases of blindness being registered annually has doubled. In the period 1933-43, on average 7000 people were newly registered blind each year; in 1990 nearly 15000 people were registered. The proportion of registrations attributed to ARMD 
over the same time period has increased markedly. In the 1930 s only $6 \%$ of the certificates analysed were attributed to ARMD; in 1990 nearly $50 \%$ of registrations were attributed to ARMD.

\section{CONTROLLING FOR CHANGES IN THE AGE} STRUCTURE OF THE POPULATION: STANDARDISED REGISTRATION RATIOS

Table 3 presents the observed and expected registrations for males and females for all registrations - ARMD, cataract, glaucoma, and optic atrophy; these data are shown graphically in Figure 2. There has been a trend of decreasing age standardised registration ratios (SRRs) for all registrations. This indicates that the rise in absolute numbers of annual registrations over time (Fig 1) can be attributed to increased numbers of older people in the population. ARMD, however, shows a different pattern with an increasing, but fluctuating trend. SRRs for cataract have decreased by a factor of 10 . There has been a smaller decrease in registrations due to glaucoma. Age standardised registration rates for optic atrophy show no consistent increase or decrease; the SRR for this condition having fluctuated in both males and females.

\section{CONTROLIING FOR DIFFERENCES IN THE} PERCENTAGE OF REGISTRATIONS FOR WHICH DATA ARE AVAILABLE

The results of taking into account differences in the percentage of registrations for which data were available in each year are presented in Table 4 and Figure 3. Adjusting the observed figures for these years has the effect of smoothing out the observed trends, largely because 1950 and 1970 had relatively low coverage at $72 \%$ and $79 \%$ respectively. The apparent downward trend in registrations for glaucoma and increasing trend for ARMD become clearer; optic atrophy appears to decrease over the time period. The adjustment has little effect on the dramatic downward trend for cataract but does, however, make it more marked.

\section{Discussion}

There has been a considerable change in the distribution of the cause of registered blindness since 1950 in England and Wales. The absolute number of annual registrations has increased and the proportion of registrations attributed to ARMD has risen from $14 \%$ to $50 \%$. Proportional analyses can be misleading so we have calculated ARMD registrations per head of population and adjusted for changes in the age structure of the population and differences in the proportion of certificates analysed. These analyses suggest that, instead of the fourfold increase suggested by the crude data, there has been an increase in registration attributed to ARMD of the order of $30 \%$. This increase is highly statistically significant and has occurred in the presence of apparently falling rates for cataract, glaucoma, and optic atrophy over the same time period.

It is important to consider possible alternative explanations for this observed increase. The increased incidence of ARMD is observed after controlling for the possible confounding effects of changes in the age structure of the

Table 3 Observed and expected registrations for all registrations, age-related macular degeneration, cataract, glaucoma, and optic atrophy 1950-90 for males and females

\begin{tabular}{|c|c|c|c|c|c|c|c|c|}
\hline & \multicolumn{2}{|l|}{ Males } & \multirow{2}{*}{$\begin{array}{l}S R R \\
(O / E)^{\star} 100\end{array}$} & \multirow[b]{2}{*}{$95 \% C I$} & \multicolumn{2}{|l|}{ Females } & \multirow{2}{*}{$\begin{array}{l}S R R \\
(O / E)^{\star} 100\end{array}$} & \multirow[b]{2}{*}{$95 \% C I$} \\
\hline & Observed & Expected & & & Observed & Expected & & \\
\hline \multicolumn{9}{|c|}{ All registrations } \\
\hline $\begin{array}{l}1950 \\
1960 \\
1970 \\
1980 \\
1990\end{array}$ & $\begin{array}{l}4603 \\
4338 \\
4018 \\
4175 \\
5085\end{array}$ & $\begin{array}{l}2950 \\
3297 \\
3348 \\
3865 \\
5085\end{array}$ & $\begin{array}{l}156 \\
132 \\
120 \\
108 \\
100\end{array}$ & $\begin{array}{l}(154-158) \\
(130-134) \\
(118-122) \\
(106-110)\end{array}$ & $\begin{array}{l}6541 \\
7343 \\
7184 \\
7466 \\
8481\end{array}$ & $\begin{array}{l}3975 \\
4953 \\
5612 \\
6595 \\
8481\end{array}$ & $\begin{array}{l}165 \\
148 \\
128 \\
113 \\
100\end{array}$ & $\begin{array}{l}(163-167) \\
(147-150) \\
(127-130) \\
(112-115)\end{array}$ \\
\hline \multicolumn{2}{|c|}{$\begin{array}{l}\chi^{2} \text { test for trend } \\
\text { ARMD registrations }\end{array}$} & \multicolumn{2}{|c|}{$p<0.001$} & \multicolumn{5}{|c|}{$p<0.001$} \\
\hline $\begin{array}{l}1950 \\
1960 \\
1970 \\
1980 \\
1990\end{array}$ & $\begin{array}{r}549 \\
1083 \\
1149 \\
1110 \\
2142\end{array}$ & $\begin{array}{l}1001 \\
1234 \\
1242 \\
1506 \\
2142\end{array}$ & $\begin{array}{r}55 \\
88 \\
93 \\
74 \\
100\end{array}$ & $\begin{array}{l}(53-57) \\
(85-90) \\
(90-95) \\
(72-76)\end{array}$ & $\begin{array}{r}780 \\
1824 \\
1464 \\
2283 \\
4438\end{array}$ & $\begin{array}{l}1698 \\
2341 \\
2739 \\
3333 \\
4438\end{array}$ & $\begin{array}{r}46 \\
78 \\
53 \\
69 \\
100\end{array}$ & $\begin{array}{l}(44-48) \\
(76-80) \\
(52-55) \\
(67-70)\end{array}$ \\
\hline \multicolumn{2}{|c|}{$\begin{array}{l}x^{2} \text { test for trend } \\
\text { Cataract registrations }\end{array}$} & \multicolumn{2}{|c|}{$\mathrm{p}<0.001$} & \multicolumn{5}{|c|}{$\begin{array}{r}4438 \\
p<0.001\end{array}$} \\
\hline $\begin{array}{l}1950 \\
1960 \\
1970 \\
1980 \\
1990\end{array}$ & $\begin{array}{l}763 \\
621 \\
493 \\
212 \\
123\end{array}$ & $\begin{array}{r}63 \\
66 \\
78 \\
90 \\
123\end{array}$ & $\begin{array}{r}1211 \\
941 \\
632 \\
236 \\
100\end{array}$ & $\begin{array}{c}(1168-1256) \\
(904-979) \\
(604-661) \\
(220-252)\end{array}$ & $\begin{array}{r}1583 \\
1480 \\
1215 \\
591 \\
329\end{array}$ & $\begin{array}{l}127 \\
173 \\
201 \\
242 \\
329\end{array}$ & $\begin{array}{r}1246 \\
855 \\
604 \\
244 \\
100\end{array}$ & $\begin{array}{c}(1216-1278) \\
(834-878) \\
(587-622) \\
(234-254)\end{array}$ \\
\hline \multicolumn{4}{|c|}{$\begin{array}{l}\chi^{2} \text { test for trend } \\
\text { Glaucoma registrations }\end{array}$} & \multicolumn{4}{|c|}{$\mathrm{p}<0.001$} & \\
\hline $\begin{array}{l}1950 \\
1960 \\
1970 \\
1980 \\
1990\end{array}$ & $\begin{array}{l}481 \\
521 \\
658 \\
460 \\
710\end{array}$ & $\begin{array}{l}356 \\
429 \\
436 \\
526 \\
710\end{array}$ & $\begin{array}{r}135 \\
121 \\
151 \\
87 \\
100\end{array}$ & $\begin{array}{c}(129-142) \\
(116-127) \\
(145-157) \\
(83-92)\end{array}$ & $\begin{array}{l}565 \\
758 \\
964 \\
689 \\
892\end{array}$ & $\begin{array}{l}352 \\
485 \\
561 \\
678 \\
892\end{array}$ & $\begin{array}{l}160 \\
156 \\
172 \\
102 \\
100\end{array}$ & $\begin{array}{c}(154-167) \\
(151-162) \\
(166-177) \\
(98-106)\end{array}$ \\
\hline \multicolumn{4}{|c|}{$\begin{array}{ll}\chi^{2} \text { test for trend } & \mathrm{p}<0.001 \\
\text { Optic atrophy registrations } & \end{array}$} & \multicolumn{4}{|c|}{$p<0.001$} & \\
\hline $\begin{array}{l}1950 \\
1960 \\
1970 \\
1980 \\
1990\end{array}$ & $\begin{array}{l}202 \\
233 \\
245 \\
148 \\
233\end{array}$ & $\begin{array}{l}157 \\
177 \\
179 \\
194 \\
233\end{array}$ & $\begin{array}{r}129 \\
132 \\
137 \\
76 \\
100\end{array}$ & $\begin{array}{c}(120-138) \\
(123-141) \\
(128-146) \\
(70-83)\end{array}$ & $\begin{array}{l}167 \\
219 \\
286 \\
162 \\
219\end{array}$ & $\begin{array}{l}134 \\
163 \\
171 \\
186 \\
219\end{array}$ & $\begin{array}{r}124 \\
134 \\
167 \\
87 \\
100\end{array}$ & $\begin{array}{c}(115-134) \\
(125-143) \\
(158-177) \\
(81-94)\end{array}$ \\
\hline \multicolumn{2}{|c|}{$x^{2}$ test for trend } & $\mathrm{p}=0$ & & \multicolumn{4}{|c|}{$\mathrm{p}<0.001$} & \\
\hline
\end{tabular}

Expected registrations calculated by applying age specific rates for 1990/91 to the population structure of year. $S R R=$ standardised registration ratio $=($ observed/expected $) \star 100$. 

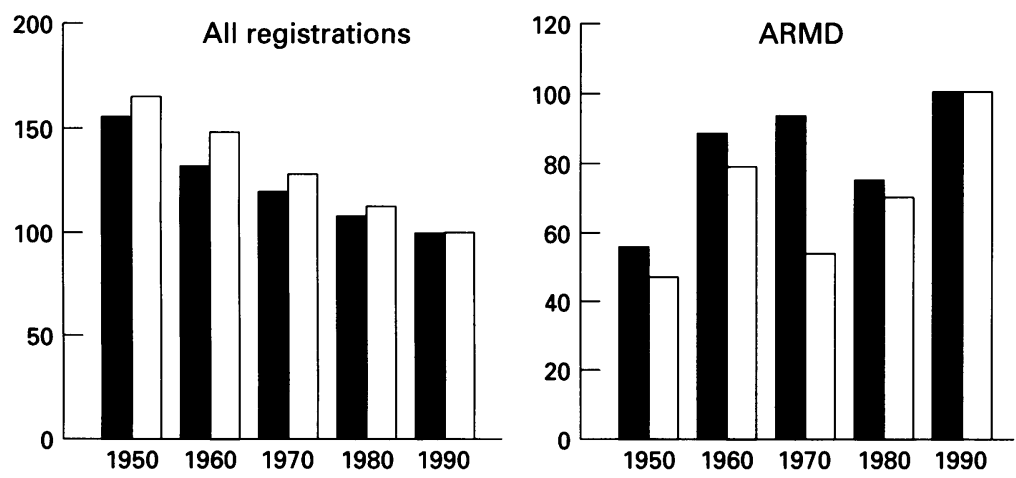

population since 1950. Data were available in 5 year age groups until the age of 85 and above which is grouped. It is possible that the observed increase reflects uncontrolled confounding in the very old age groups. Examination of age specific rates of ARMD registration between 1980 and 1990 indicates that there has not been a disproportionate increase in the registration rate in the very elderly; however, this potential alternative explanation will be addressed more adequately when data for the year 2000 are available, thus enabling direct comparison of age specific rates over a 20 year period.

Sorsby estimated the blindness register to be
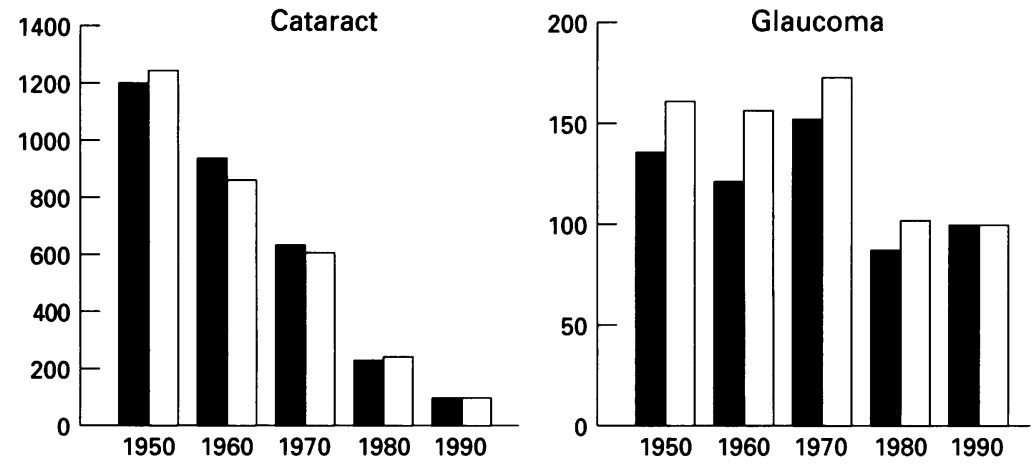
$85-90 \%$ complete in the 1950 s but did not provide any data to support his view. ${ }^{10}$ It is not known whether the completeness of registration has changed since that time. A small population based study in England in the mid 1980s also found blindness registration to be $90 \%$ complete. ${ }^{23}$ In contrast, the RNIB survey ${ }^{3}$ estimated $64 \%$ of people with visual acuity of less than $6 / 60$ (measured in the home) to be unregistered. The survey report, however, did not indicate possible remediation of the visual deficit, therefore it is not clear what proportion of people with this level of visual deficit would be appropriately registered with irremediable conditions.

The aim in comparing trends in ARMD with other causes was to attempt to overcome the difficulty of possible (unknown) changes in completeness of registration over time, the assumption being that any changes would be reflected equally among all the different causes. The number of causes for which sufficient data were available to permit analysis was limited and for this reason cataract, glaucoma, and optic atrophy were chosen. This choice was a priori - no other causes were examined.

The assumption underlying these comparisons may not be valid if any general increase in

Figure 2 Standardised registration ratios for all registrations, age-related macular degeneration (ARMD), cataract, glaucoma, and optic atrophy 1950-90 for males and females.

Table 4 Observed and expected registrations for age-related macular degeneration, cataract, glaucoma, and optic atrophy 1950-90 for males and females: adjusting for the percentage of registrations analysed

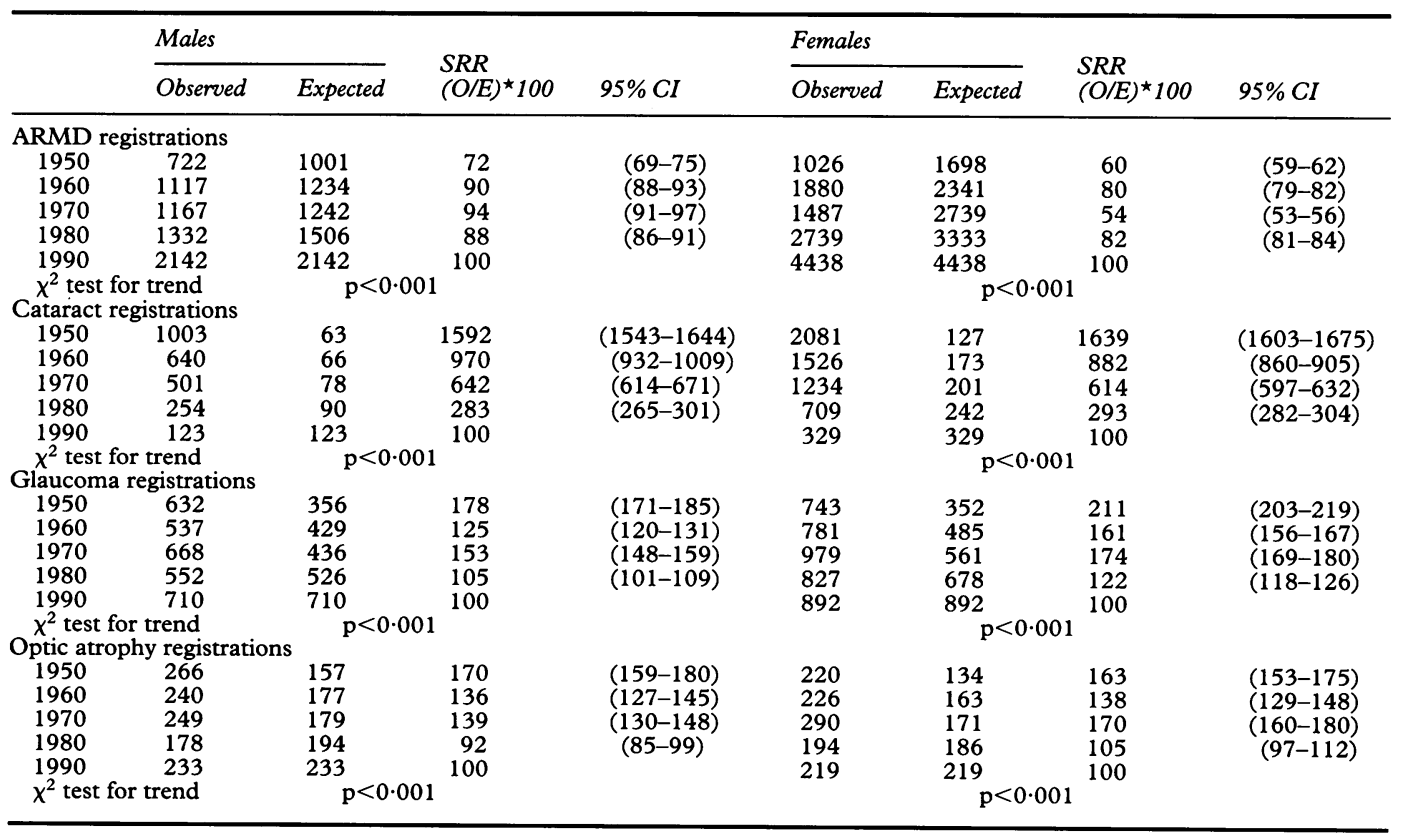

Expected registrations calculated by applying age specific rates for 1990/91 to the population structure of year. 

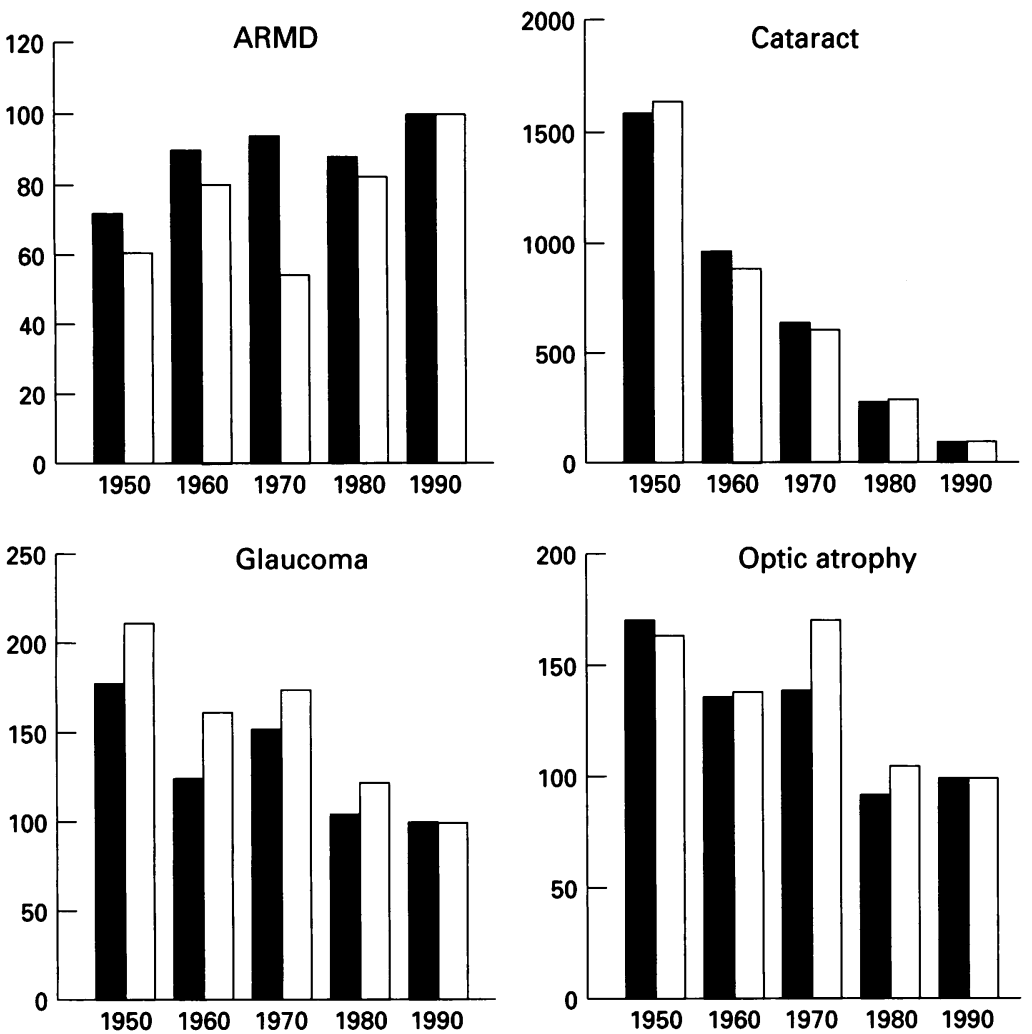

Males $\square$ Females

Figure 3 Standardised registration ratios for age-related macular degeneration (ARMD), cataract, glaucoma, and optic atrophy 1950-90 for males and females adjusting for the percentage of registrations analysed.

uptake of registration was masked, in the case of cataract and glaucoma, by the underlying trend for decreased registration of these causes owing to improvements in treatment over the time period. Trends in registration of people with largely untreatable conditions such as optic atrophy appear to be decreasing. If one was to argue that the uptake of registration was increasing then one would expect an increase in registration of such a condition to the same degree as ARMD.

Similarly there may be difficulties in these comparisons if changes in detection and/or classification of these conditions have occurred. The terms used to describe cataract, glaucoma, and optic atrophy are set out in Table 2. It is unlikely that the classification of blinding cataract has changed since 1950 . The detection and diagnosis of congenital cataract is more problematic. This has been tabulated fairly consistently separately from congenital cataract and we have excluded it from our analyses. Although the definition of glaucoma is problematic it is likely that the severity of blinding glaucoma is such that the diagnosis is relatively unambiguous. With improvements in perimetry and the glaucoma service since 1950 , the detection and diagnosis of this condition may well have improved; this conflicts with the apparently falling rate of registration for blindness reported here. The classification of optic atrophy is the most problematic. The published reports are unambiguous in the terms used to describe optic atrophy but again there is little discussion of coding rules, for example, as to whether this condition is counted as an entity in its own right, or tabulated under the systemic or ocular condition leading to its development.

Senile macular degeneration was first described as a clinical entity by Haab in 1885 . Although the clinical features of the disease are described in detail in textbooks in $1940,{ }^{24}$ the absolute numbers of cases in 1950 was much smaller and it is difficult to assess the effect of reporting bias potentially introduced by the fact that ARMD formed a much greater proportion of ophthalmologists' workloads in 1990. Examination of a series of textbooks covering the 40 year time period ${ }^{24-27}$ suggests the most notable shift in perception of this disease has not been in description of the lesions involved so much as in the fact that this condition used to be considered under both 'diseases of the uveal tract' and 'diseases of the retina', whereas now it is exclusively described under 'diseases of the retina'.

The reports of published data on registration contain little discussion of coding rules or possible misclassification. Sorsby used the term 'senile macular degeneration' in the 1930s and fairly consistently up until and including 1950. In the period after 1950 he used 'senile macular lesions' more often but not exclusively and close examination of his reports for that period reveal that he used the terms 'senile macular lesions' and 'senile macular degeneration' interchangeably. The classification for 1970 is more problematic. The significance of 'macular lesions' is unclear; although cases of macular lesions largely consist of older people, the fact that the term indicating 'senile' or 'age related' was dropped indicates that there is a possibility that macular lesions of other aetiology - for example, diabetic, hereditary, or toxic maculopathies are included in here. An analysis of data coded in $1990 / 91$ (the standard year) suggested that coding, at least in 1991, was reasonably accurate with probable misclassification of only $2 \%$ for ARMD, 3\% for glaucoma, and $1.6 \%$ for cataract. ${ }^{28}$ The only category in the published reports to which ARMD might have been attributed in previous years is 'chorioretinal atrophy'. This is not tabulated consistently over the time period; however, in $\mathbf{1 9 5 0}$ nearly 600 cases of choroidal atrophy caused by myopia were recorded, in contrast with 1990 where 91 cases of 'choroidal degeneration' were counted and 235 cases of myopia.

\section{CONCLUSIONS AND IMPLICATIONS}

In terms of the number of people affected, there is an epidemic of blinding ARMD in Britain. Whether this is over and above that expected as a result of the changing demography of the population is in question. We have been unable to explain adequately an observed increase of the order of $30-40 \%$ in age standardised registration due to ARMD in England and Wales over the past 40 years. It is difficult to exclude potential sources of bias from these registration data. We believe this increase may well be due to an evolution in the classification of this condition, perhaps in 
respect of the differential diagnosis of myopic degeneration, but do not have the data to test this hypothesis.

These analyses highlight the importance of collecting and publishing routine statistics on blindness in such a way as to permit confident analysis. Standardised definitions, critical assessment of possible misclassification, and regular assessment of the coverage of registration are needed. With the development of a computerised database of data on cause collected during the course of registration this is theoretically possible. The next analyses are planned for the year 2000 . It will then be possible to compare age specific registration for more finely stratified age groups (particularly for ages over 85 years) directly for 1990 and 2000 and standardised classification and coding (ICD) will have been in use for 20 years.

We gratefully acknowledge the ophthalmologists who have completed BD8 forms over the years without whom these data completed BD8 forms

due to John Ashley, Cleone Rooney, and Many thanks are due to John Ashley, Cleone Rooney,
Nirupa Dattani at OPCS for supplying the data for 1990.

1 MacMahon B, Pugh TF. Epidemiology: principles and methods. Boston: Little, Brown, 1970.

2 Department of Health. Coordinating services for visually handicapped people: report to the minister for the disabled. London: HMSO, 1989.

3 Bruce I, McKennell A, Walker E. Blind and partially sighted adults in Britain: the RNIB survey. Volume 1. London: HMSO, 1991.

4 Evans JR. Causes of blindness and partial sight in England and Wales 1990-1991. Studies on medical and population subjects 57. London: HMSO, 1995.

5 The Eye Disease Case-Control Study Group. Rick factors for neovascular age-related macular degeneration. Arch Ophthalmol 1992; 110: 1701-8.

6 Heiba IM, Elston RC, Klein BE, Klein R. Sibling correlations and segregation analysis of age-related maculopathy: the Beaver Dam Eye Study. Genet Epidemiol 1994; 11 51-67.

7 Taylor HR, West S, Munoz B, Rosenthal FS, Bressler SB Bressler NM. The long-term effects of visible light on the eye. Arch Ophthalmol 1992; 110: 99-104.

8 Christen WG. Antioxidants and eye disease. Am $\mathcal{f} \mathrm{Med}$ 1994; 97 (suppl 3A): 14-7S.
9 Sorsby A. Medical Research Council Memorandum no 24: The causes of blindness in England and Wales. London: HMSO, 1950.

10 Sorsby A. The causes of blindness in England 1948-1950. London: HMSO, 1953.

11 Sorsby A. Blindness in England 1951-1954. London: HMSO, 1956.

12 Sorsby A. The incidence and causes of blindness in England and Wales 1948-62. Reports on public health and medical subjects 1966: 114 .

13 Sorsby $A$. The incidence and causes of blindness in England and Wales 1963-8. Reports of public health and medical subjects 1972: 128 .

14 Department of Health and Social Security. Blindness and partial sight in England 1969-1976. Reports of public health and medical subjects 1979: 129.

15 Department of Health and Social Security. Causes of blindness and partial sight among children aged under 16 newly registered as blind and partially sighted between 1976 and 1985. Statistical Bulletin DHSS 1986: 5/86.

16 Government Statistical Service. Causes of blindness and partial sight among adults in 1976/77 and 1980/81. London: HMSO, 1988 .

17 Department of Health and Social Security. Causes of blind ness and partial sight among children aged 16-64 newly registered as blind and partially sighted between $1985 / 6$. Statistical Bulletin DHSS 1992: 3/8/88.

18 Department of Health and Social Security. Causes of blindness and partial sight among children aged under 16, newly registered as blind and partially sighted Apri 1985-March 1987. Statistical Bulletin DHSS 1987: $5 / 86$.

19 Department of Health. Causes of blindness and partial sight among children aged under 16 , newly registered as blind or partially sighted between April 1987 and March 1990 or partially sighted between Ap
Statistical Bulletin 1991: 3(5)91.

20 WHO. International classification of diseases, 9 th revision. Geneva: WHO, 1977.

21 OPCS. Population estimates, series PP1, vols 1-6. London: HMSO, 1983.

22 Breslow NW, Day NE. Statistical methods in cancer research. Volume II: The design and analysis of cohort studies. Lyons: IARC Scientific Publications no 82, 1987

23 Gibson JM, Lavery JR, Rosenthal AR. Blindness and partia sight in an elderly population. $\mathrm{Br} \mathcal{F}$ Ophthalmol 1986; 70: $700-5$.

24 Duke-Elder WS Textbook of ophthalmology Volume III. Diseases of the inner eye. London: Henry Kimpton, 1940: 2372-4

25 Duke-Elder S. Parsons' diseases of the eye. 13th ed. London: J \& A Churchill Ltd, 1959.

26 Duke-Elder S, Perkins ES. System of ophthalmology: Volumes IX. Diseases of the uveal tract. London: Henry Kimpton, 1966.

27 Duke-Elder S, Dobree JH. System of ophthalmology. Volume X. Diseases of the retina. London: Henry Kimpton, 1967.

28 Evans JR, Wormald RPL. Epidemiological function of BD8 certification. Eye 1993; 7: 172-9. 